\title{
MIGRACIÓN INDÍGENA HACIA ESPACIOS AGRÍCOLAS MARGINADOS DE MÉXICO. UN CASO PARA CONTAR
}

\author{
INDIGENOUS MIGRATION TOWARDS MARGINALIZED AGRICULTURAL SPACES IN \\ MÉXICO: A CASE TO BE TOLD
}

\author{
José P. Juárez-Sánchez
}

Campus Puebla. Colegio de Postgraduados (pjuarez@colpos.mx)

\begin{abstract}
RESUMEN
Ante la demanda de mano de obra escasamente calificada se promueve el libre mercado de trabajo y en los espacios rurales se aplica una política agrícola desfavorable a la producción de granos básicos y de café. Una consecuencia es el incremento del nivel de pobreza de la población rural indígena; de la migración a espacios agrícolas capitalizados. Mediante el muestreo no estadístico denominado "bola de nieve" se determinó una muestra de 76 jornaleros agrícolas que migraron de regiones indígenas a laborar en el municipio de Calpan, Puebla. Los resultados indican que los migrantes jornaleros mantienen las características de sus regiones de origen, y las principales causas de la migración son la pobreza y el escaso empleo en las comunidades de donde provienen. Son empleados en Calpan por la falta de mano de obra en este municipio para realizar la cosecha de sus cultivos; los ingresos que obtienen son superiores a los de su lugar de origen y la mayoría expresó que viven mejor en esta región que en su lugar de procedencia. Se concluye que la migración es estacional e intrarregional y contribuye a mejorar las condiciones de vida de los jornaleros en sus espacios de origen.
\end{abstract}

Palabras clave: campesino, desigualdad, espacios marginados, migración interna, pobreza.

\section{INTRODUCCIÓN}

$\longrightarrow$ on la adopción del modelo neoliberal, en la mayoría de los países en desarrollo se implementaron estrategias que pueden englobarse bajo el concepto de reestructuración, con el objetivo de impulsar el crecimiento económico en un mundo global. Se fomenta el retiro del Estado y se pondera su inserción en el mercado internacional, aprovechando las ventajas comparativas a través de la exportación

* Autor responsable $*$ Author for correspondence.

Recibido: octubre, 2014. Aprobado: enero, 2015.

Publicado como ARTíCULO en ASyD 12: 87-105. 2015.
Facing the demand for scarcely qualified workforce, the free labor market is promoted and an unfavorable agricultural policy is applied in rural spaces to the production of basic grains and coffee. One consequence is an increase in the level of poverty of rural indigenous populations and migration to capitalized agricultural spaces. Through the non-statistical sampling method called "snowball", a sample of 76 agricultural day laborers was determined, who migrated from indigenous regions to work in the municipality of Calpan, Puebla. The results indicate that migrant day laborers keep characteristics from their regions of origin and that the main causes for migration are poverty and scarce employment in the communities where they are from. They are employed in Calpan because of the lack of workforce in this municipality to harvest crops; the income they obtain is higher than in their places of origin; and, most expressed that they live better in this region than in their places of origin. The conclusion is that migration is seasonal and intra-regional, and that it contributes to improve the living conditions of day laborers in their spaces of origin.

Key words: peasant, inequality, marginalized spaces, domestic migration, poverty.

\section{INTRODUCTION}

W ith the adoption of the Neoliberal model in most developing countries, strategies were implemented that can be framed under the concept of restructuring, with the objective of driving economic growth in a global world. The withdrawal of the State is promoted and its insertion into the international market is extolled, using the comparative advantages through the export of work-intensive products (Guillén, 2007). The United Nations Development Program (PNUD, 2013) mentions that developing countries 
de productos intensivos en trabajo (Guillén, 2007). El Programa de las Naciones Unidas para el Desarrollo (PNUD, 2013) menciona que los países en desarrollo lograron un mayor progreso económico; entre 1980 y 2010 su participación en el comercio internacional de mercancías se incrementó de $25 \%$ a $47 \%$ y su contribución a la producción mundial pasó de $33 \%$ a $45 \%$. Se ha logrado un importante crecimiento económico no solo en las naciones, sino fundamentalmente de las empresas transnacionales; en contraparte, existe crecimiento y agudización de la pobreza de la mayor parte de la población. De acuerdo con el Banco Mundial (2014), en 2013 existían 7124.50 millones personas en el mundo, en América Latina, 588 millones y en México, 122.3 millones de habitantes. Este organismo menciona que en 2012, $47 \%$ de la población del mundo vivía en los espacios rurales. Estos datos muestran que los países con menor desarrollo tienen más población rural.

Con respecto a la distribución de los ingresos en el mundo, 848.7 millones de personas se clasificaban como de bajos ingresos, 4969.7 millones son de ingresos medios y 1306.1 millones de ingresos altos. Asimismo, de acuerdo con el tipo de desarrollo, 72\% vivía en países de bajos ingresos; en América Latina representaban $21 \%$ y en México $22 \%$ (Banco Mundial, 2014). En 2002 la pobreza en América Latina alcanzó $43.9 \%$ de esta población y en 2012 representaba $28.3 \%$; en México fue $37.1 \%$ y la indigencia de $14.2 \%$ (CEPAL, 2013). La población indígena es una de las más pobres y marginadas de México; en 2013 existían 11517017 de indígenas (Consejo Nacional de Población-CONAPO, 2014) y, de acuerdo con el Instituto Nacional de Estadística y Geografía (INEGI, 2011), 62\% habita en comunidades con menos de 2500 residentes y $73.3 \%$ residía en los 125 municipios con menor Índice de Desarrollo Humano.

Estos resultados, en parte, son consecuencia de la crisis económica y de las estrategias de desarrollo de las empresas; el neoliberalismo ha fracasado con respecto a la distribución del ingreso entre la población, y en el ámbito económico ha beneficiado fundamentalmente a las empresas transnacionales. Boisier (2006) menciona que la teoría económica se ha preocupado más del crecimiento que del desarrollo y ha conducido a una crisis social, reflejada en la inequidad y la exclusión, cuando no todos los miembros de la sociedad tienen las mismas oportunidades achieved greater economic progress; between 1980 and 2010, their participation in international trade of merchandises increased from $25 \%$ to $47 \%$, and their contribution to global production went from $33 \%$ to $45 \%$. An important economic growth has been achieved not only in nations, but rather mainly in transnational enterprises; in contrast, there is an increase and worsening of poverty in most of the population. According to the World Bank (2014), in 2013 there were 7124.50 million people in the world, 588 million in Latin America, and 122.3 million inhabitants in México. This organization mentions that in 2012, $47 \%$ of the world population lived in rural spaces. These data show that the countries with least development have a higher rural population.

With regard to income distribution in the world, 848.7 million people were classified as having low income, 4969.7 million as mid-income, and 1306.1 million as high income. Likewise, based on the type of development, $72 \%$ lived in low-income countries; in Latin America they represented $21 \%$ and in México $22 \%$ (Banco Mundial, 2014). In 2002 poverty in Latin America reached $43.9 \%$ of the population and in 2012 it represented 28.3\%; in México, it was $37.1 \%$ and destitution $14.2 \%$ (CEPAL, 2013). The indigenous population is one of the poorest and most marginalized in México; in 2013 there were 11 517017 indigenous people (Consejo Nacional de Población-CONAPO, 2014), and according to the National Statistics and Geography Institute (INEGI, 2011), $62 \%$ reside in communities with less than 2500 inhabitants, and $73.3 \%$ reside in the 125 municipalities with lowest Human Development Index.

These results are consequence, in part, of the economic crisis and the development strategies of enterprises; Neoliberalism has failed with regard to income distribution among the population, and in the economic scope it has benefitted mainly transnational companies. Boisier (2006) mentions that the economic theory has been more concerned with growth than with development, and has led to a social crisis, reflected in inequality and exclusion, where not all members of society have the same equity in opportunities to decide the manner in which they wish to satisfy their needs (Portales, 2014). Such is the case of the municipalities in the study, which are characterized as practicing smallscale agriculture. 
para decidir la manera en que desean satisfacer sus necesidades (Portales, 2014). Es el caso de los municipios de estudio, que se caracterizan por practicar una agricultura minifundista.

En 2009 el Producto Interno Bruto (PIB) cayó a escala global, el desempleo se elevó, la ocupación disminuyó y la pobreza e indigencia aumentaron. Entre la población de los países en subdesarrollo se impulsan estrategias para paliar la pobreza a la que están sometidos, y una de ellas es la migración. A nivel mundial, en 1980 existían 102 millones de migrantes, los cuales ascendieron a 231.5 millones en 2013 (Serrano, 2014); en dicho periodo la migración se incrementó $126.9 \%$ y representó $3.2 \%$ de la población mundial. Los migrantes son originarios de países en desarrollo $(80.6 \%)$ con destino hacia naciones desarrolladas. A escala mundial México ocupa el segundo lugar en emigración con 13.2 millones; la India tiene el primero con 14.2 millones y el cuarto en captación de remesas con 22 millones de dólares. La migración mexicana tiene como principal destino los Estados Unidos y específicamente los estados de California y Texas; se emplean $(64.6 \%)$ en el sector terciario (Serrano, 2014).

La migración interna en México se da principalmente hacia el Estado de México, el Distrito Federal y Veracruz. Sus causas son dinámicas y están en función del modelo económico y el tipo de espacio. En América Latina y El Caribe en las últimas décadas la migración indígena aumentó a escala internacional y responde a una estrategia de supervivencia de individuos y grupos hacia diferentes espacios. En México, en 2000, más de un millón de indígenas nacieron en una entidad federativa distinta en la que fueron censados y casi 20 mil nacieron en otro país (INMUJERES/CONAPO/CDI/SSA, 2006). Herrera et al. (2010) mencionan que en las tres últimas décadas se observa una creciente presencia de indígenas mexicanos en Estados Unidos y que están reemplazando en las actividades agrícolas a los migrantes de las regiones migratorias tradicionales.

Sánchez (2001) argumenta que el incremento de los migrantes indígenas y sus condiciones de trabajo están en relación directa con los patrones migratorios que se han conformado para este grupo de asalariados en la producción de cultivos de exportación en el noroeste de México. A inicios del siglo, Mendoza (2010) identificó ocho polos de atracción de esta población en el país, destacando el Estado de México,
In 2009, the Domestic Gross Product (GDP) dropped at the global scale, unemployment increased, employment decreased and poverty and destitution increased. Among the population in underdeveloped countries, strategies are promoted to alleviate the poverty they are subject to, and one of them is migration. At the global level, in 1980 there were 102 million migrants, which increased to 231.5 million in 2013 (Serrano, 2014); during this period, migration increased in $126.9 \%$ and represented $3.2 \%$ of the world population. Migrants are originally from developing countries $(80.6 \%)$ with developed nations as destination. At the global scale, México occupies the second place in emigration, with 13.2 million; India is the first place with 14.2 million and the fourth in remittance capture with 22 million dollars. Mexican migrants have the United States as main destination, and specifically the states of California and Texas; they are employed (64.6\%) in the tertiary sector (Serrano, 2014).

Domestic migration in México occurs primarily towards Estado de México, Distrito Federal and Veracruz. Its causes are dynamic and in function of the economic model and type of space. In Latin America and the Caribbean, during recent decades, indigenous migration increased at an international scale and responds to a survival strategy by individuals and groups towards different spaces. In México, in 2000 , more than one million indigenous people were born in a state different to the one where they were registered in the census, and almost 20 thousand were born in a different country (INMUJERES/ CONAPO/CDI/SSA, 2006). Herrera et al. (2010) mention that in the last three decades, a growing presence of Mexican indigenous people can be observed in the United States, and that they are replacing in agricultural activities the migrants from traditional migratory regions.

Sánchez (2001) argues that the increase in indigenous migrants and their working conditions are in direct relation to the migratory patterns that have been established for this group of paid workers in the production of export crops in northwestern México. At the beginning of the century, Mendoza (2010) identified eight attraction poles for this population in the country, with the following standing out: Estado de México, Distrito Federal, Sinaloa-Baja California, Yucatán-Quintana Roo, Durango-Chihuahua, Veracruz-Tamaulipas, Veracruz-Puebla, Oaxaca- 
Distrito Federal, Sinaloa-Baja California, YucatánQuintana Roo, Durango-Chihuahua, VeracruzTamaulipas, Veracruz-Puebla, Oaxaca-Veracruz y Jalisco-Veracruz. La expulsión de la población rural e indígena parte de la zona centro del país y considera al Distrito Federal y a los estados de Guerrero, Hidalgo, México, Morelos, Oaxaca, Puebla, Querétaro y Tlaxcala (Rojas, 2009), pero las principales entidades expulsoras de población son Veracruz y Oaxaca (Mendoza, 2010). Este mismo autor señala que en 2000, en la Sierra Norte de Puebla y Totonacapan, más de 800 mil personas habitaban la región y que cinco años después alrededor de 11571 personas habían migrado, siendo el Distrito Federal su principal destino. El objetivo de la investigación fue analizar las causas y el tipo de migración indígena a espacios rurales. Como hipótesis se planteó que los migrantes salen de su territorio por el deterioro económico y la agudización de la pobreza.

\section{DE LA MIGRACIÓN RURAL-URBANA A LA MIGRACIÓN INDÍGENA A ESPACIOS RURALES MARGINADOS}

En las últimas décadas se han impulsado cambios estructurales en las economías de los países. Ello significó la coalición entre el capital financiero mundial y los bloques locales para transformar al Estado benefactor y hacerlo eficaz con sus objetivos económicos y financieros. La liberalización y desregulación son los pilares de la financiarización que es impulsada por el Estado, tanto en los países avanzados como en las economías emergentes (Mendoza, 2012). Una de las consecuencias de las medidas económicas de corte neoliberal es el incremento de la pobreza y la migración laboral; esta última es considerada como una estrategia de supervivencia para la población y de desarrollo para los gobiernos. En ese sentido, García (2010) menciona que las migraciones son funcionales al modelo, ya que son una válvula de escape a una población laboral que no es absorbida en sus países de origen y contribuye a satisfacer la demanda laboral, además de generar importantes flujos de remesas con efectos macroeconómicos significativos a escala nacional, regional y familiar.

De acuerdo con la Organización Internacional para las Migraciones (OIM), la migración laboral debe entenderse como el movimiento de personas de un espacio geográfico a otro, cruzando fronteras
Veracruz and Jalisco-Veracruz. The expulsion of rural and indigenous population starts from the central part of the country and includes Distrito Federal and the states of Guerrero, Hidalgo, México, Morelos, Oaxaca, Puebla, Querétaro and Tlaxcala (Rojas, 2009), but the main states expulsing population are Veracruz and Oaxaca (Mendoza, 2010). This same author points out that in 2000, in Puebla's Sierra Norte and Totonacapan, more than 800 thousand people resided in the region, and that five years later around 11571 people had migrated, with Distrito Federal as their main destination. The objective of the study was to analyze the causes and type of indigenous migration towards rural spaces. The hypothesis set out is that migrants leave their territories as a result of economic deterioration and worsening of poverty.

\section{From RURAL-URBAN MIGRATION TO INDIGENOUS MIGRATION TOWARDS MARGINALIZED RURAL SPACES}

During recent decades, structural changes in countries' economies have been promoted. This means a coalition between the global financial capital and local blocks, in order to transform the welfare State and make it effective with its economic and financial objectives. Liberalization and deregulation are the pillars of the type of financing driven by the State, both in advanced countries and in emerging economies (Mendoza, 2012). One of the consequences of the Neoliberal economic measures is the increase in poverty and labor migration; the latter is considered a survival strategy for the population and a development strategy for governments. In this sense, García (2010) mentions that migrations are functional for the model, since they are an escape valve for a working population that is not absorbed in its countries of origin and which contributes to satisfying the labor demand, in addition to generating important remittance fluxes with significant macroeconomic effects at the national, regional and family scales.

According to the International Organization for Migration (IOM), labor migration must be understood as the movement of people from one geographic space to another, crossing administrative or political borders, and who wish to be established temporally or definitively in a different place from their place of origin. This means that migration 
administrativas o políticas, y que desean establecerse temporal o definitivamente en un lugar distinto a su lugar de origen. Ello significa que la migración es el desplazamiento físico de las personas a otras unidades administrativas. Arango (2003) menciona que son producto de la desigual distribución espacial del trabajo y capital, donde los trabajadores tienden a desplazarse a las regiones en las que la mano de obra es escasa y los salarios elevados; entonces, no sólo son transiciones espaciales, sino también sociales (Arango, 1985) y económicas. Se considera que la razón fundamental de la migración laboral es económica, tal como lo señaló Ravenstein (1885), y a más de 100 años este tipo de fundamento sigue vigente.

La política de flexibilización laboral promueve la mano de obra barata hacia los espacios demandantes, impulsando políticas que desalientan a los productores minifundistas a seguir laborando en la agricultura. De acuerdo con Ruiz y Delgado (2008), se impulsa la des-ruralización, que permite recuperar las tasas de ganancia y garantiza el proceso de acumulación de capital. Se puede decir que la acentuación de la migración rural y, en especial, la indígena, en las últimas décadas es producto de las políticas agrícolas reflejadas en los bajos precios de sus productos, escasos subsidios y desatención al campo. Bermúdez (2008) argumenta que la migración obedece al aumento de miembros de la familia, a la introducción de técnicas modernas, a la imposibilidad de competir con las empresas modernas del sector y al dominio de las empresas transnacionales que se imponen a través de la violencia, directa o indirecta, además de la aplicación de legislaciones que benefician a los monopolios. Estas medidas, en su conjunto, han llevado a la agricultura de subsistencia a un estado permanente de crisis económica.

Los flujos migratorios no solo parten de aquellos espacios rurales en crisis, sino también de los lugares que tienen importantes recursos naturales. En ellos el Estado implementa políticas que estimulan la demanda creciente de estos recursos; es el caso del petróleo y los minerales, el agua y la biodiversidad, entre otros. Otra estrategia complementaria a la anterior es el impulso de la neo reforma agraria, que fomenta el libre mercado de la tierra. Sus consecuencias han significado el despojo o compra de sus tierras, obligando a los habitantes originales a desplazarse en distintos sentidos y alcances a partir de los cambios producidos en los centros del capitalismo mundial is the physical displacement of people to other administrative units. Arango (2003) mentions that it is a product of the unequal spatial distribution of work and capital, where workers tend to move to regions where labor is scarce and salaries high; thus, they are not only spatial transitions, but also social (Arango, 1985) and economic. It is considered that the fundamental reason for labor migration is economic, as Ravenstein (1885) pointed out, and this type of argument still prevails after more than 100 years.

The policy for labor flexibilization promotes the displacement of cheap labor towards the demanding spaces, fostering policies that discourage small-scale farmers to continue to work in agriculture. According to Ruiz and Delgado (2008), de-ruralization is promoted, which allows recuperating the profit rates and guarantees the process of capital accumulation. It can be said that the emphasis in rural migration and, particularly, indigenous migration, during recent decades is a product of the agricultural policies reflected in the low prices of their products, scarce subsidies and inattention to the countryside. In his turn, Bermúdez (2008) argues that migration responds to the increase in the number of family member, the introduction of modern techniques, the impossibility to compete with modern enterprises in the sector, and the dominion of transnational enterprises that are imposed through violence, direct or indirect, in addition to the application of laws that benefit monopolies. These measures, as a whole, have led subsistence agriculture to a permanent state of economic crisis.

Migratory fluxes not only stem from those rural spaces in crisis, but also from the places that have important natural resources. In them, the State implements policies that stimulate the growing demand of those resources; it is the case of oils and minerals, water and biodiversity, among others. Another complementary strategy to the latter is the boost to the agrarian neo-reform, which promotes free market of the land. Its consequences have meant the dispossession or purchase of people's lands, forcing the original inhabitants to move in different directions and reaches, in response to the changes produced in the centers of global capitalism (Escárzaga, 2004). In face of this, farmers are not left with another option other than diversifying their agricultural and livestock activities, seeking 
(Escárzaga, 2004). Ante ello, a los agricultores no les queda más que diversificar sus actividades agropecuarias, buscar empleo no agrícola y, en su caso, migrar a otros espacios que le permitan mejorar sus condiciones de vida.

Los desplazamientos de indígenas se realizan fundamentalmente hacia los espacios agrícolas de exportación, no sin olvidar que también se emplean en el comercio informal en las ciudades y que su incorporación en la industria maquiladora es incipiente (Velasco, 2010). Estos espacios desterritorializados se caracterizan por ser demandantes de mano de obra barata y, a través de sus políticas económicas, el Estado busca satisfacerla; ello explica, en parte, el desplazamiento de las personas indígenas hacia estos espacios. Además, los empleos y los niveles educativos son de baja calificación y los espacios con una agricultura capitalizada orientada a la exportación son proclives a emplear a este tipo de mano de obra (Velasco, 2010) ya que, al incorporar y adaptar nuevas estrategias productivas, similares a la especialización flexible (Lara, 1996) buscan, principalmente, disminuir costos a través de los salarios. Las grandes empresas agropecuarias buscan una mano de obra flexible y aprovechan las ventajas comparativas de los territorios. En los espacios agrícolas no capitalizados buscan sustituir la mano de obra que ha migrado o que no desea trabajar en la agricultura por salarios bajos.

Una de las consecuencias de la migración laboral es su contribución a la proletarización del campesinado. En ese sentido, Monroy y Juan (2009:) argumentan que el proceso de descampesinización ha dado lugar al nacimiento del proletariado agrícola y el cual, con mayor o menor grado de violencia, es arrancado de la tierra, y que este fenómeno está relacionado con el proceso de acumulación de capital y con la migración. En este contexto, Tierry (2001) menciona que las unidades de producción tienden a disminuir su número y que este proceso es acompañado de profundos cambios en el perfil sociológico de los productores: las unidades de producción campesinas (UPC) pasan de un modelo familiar de corte chayanoviano a un modelo de agricultura de pareja que cuida la finca, y los hijos estudian o migran a la ciudad; sin embargo, se considera que no existe tal desaparición del campesinado indígena. Se podría decir que en el medio rural surge una respuestas de los campesinos en lo económico, político y social, non-agricultural employment and, in such a case, migrating to other spaces that allow them to improve their living conditions.

Indigenous displacements are done fundamentally towards export agricultural spaces, without forgetting that indigenous people are also employed in the informal commerce in cities and that their incorporation to the maquiladora industry is incipient (Velasco, 2010). These de-territorialized spaces are characterized by being demanding for cheap labor and the State seeks to satisfy it through its economic policies; this explains, in part, the displacement of indigenous people towards these spaces. Also, the jobs and educational levels are of low-qualification, and the spaces with capitalized agriculture directed at export are prone to employ this type of workforce (Velasco, 2010), since they seek, primarily, to decrease costs through salaries when incorporating and adapting new productive strategies, similar to flexible specialization (Lara, 1996). Large agricultural/livestock enterprises seek a flexible workforce and to take advantage of the comparative advantages of the territories. In noncapitalized agricultural spaces, they seek to substitute the workforce that has migrated or that does not want to work in agriculture because of the low wages.

One of the consequences of labor migration is its contribution to peasants becoming proletarians. In this sense, Monroy and Juan (2009) argue that the process of de-peasantry has given rise to the birth of the agricultural proletariat, who, with higher or lower degree of violence, are ripped from the land; and that this phenomenon is related to the process of capital accumulation and migration. Within this context, Tierry (2001) mentions that the production units tend to decrease their number and that this process is accompanied by deep changes in the sociological profile of producers: peasant production units (PPU) change from a Chayanov family model to an agriculture model based on a couple who manage the farm and their children who study or migrate to the city; however, it is considered that such a disappearance of the indigenous peasantry is not happening. It could be said that in the rural environment there is a surge of answers from peasants in economic, political and social terms, resulting in a socioeconomic reconfiguration and recomposition, as response to economic globalization. In the case of domestic indigenous migrants, they make use of 
que implica una reconfiguración y recomposición socioeconómica del territorio, como respuesta a la globalización económica. En el caso de la migración interna indígena, aprovecha la demanda de trabajo cíclica en la agricultura para diversificar el ingreso de la familia e invertir parte de los recursos económicos que obtiene como jornalero en la UPC.

Estas personas son contratadas por día o tarea, con escasas o nulas garantías de estabilidad laboral, y su ingreso está condicionado por la sobreabundancia de trabajadores eventuales que se movilizan con este fin, lo cual permite mantener sus salarios bajos (Sánchez, 2005). Se puede decir, que en su mayoría, los trabajos son temporales o estacionales y ante ello los migrantes han creado rutas de migración laboral o, en su caso, regresan a su lugar de origen. En las rutas, los migrantes aprovechan la producción cíclica de los productos agrícolas de los diferentes espacios que demandan mano de obra (Velasco, 1995). Estamos frente a una migración temporal que se considera un mecanismo de explotación empleado por el capital para apropiarse de la mano de obra, cuyo costo de producción y reproducción se paga parcialmente (Balán, 1980).

Este tipo de inmigrantes tienen una movilidad y residencia estacional en circuitos geográficos, más o menos definidos por el mercado agrícola y una especialización laboral como jornaleros en cultivos específicos (Velasco, 2014). En su mayoría, los indígenas regresan en el corto plazo a su comunidad de origen en función del ciclo agrícola de su UPC, aprovechando que estos sistemas se asocian con cultivos caracterizados por el uso intensivo de mano de obra, cuya demanda se concentra en periodos específicos del ciclo agrícola (Sánchez, 2001). Se considera que la movilidad indígena está asociada a la cosecha de la producción agrícola de exportación en diferentes puntos, a los lazos de identidad o pertenencia y a la atención de su unidad de producción familiar. La migración se constituye en una estrategia de supervivencia de las UPC, entendiendo que ésta pertenece a una clase social y que, en función de las condiciones de vida que se derivan de dicha pertenencia desarrollan, deliberadamente o no, determinados comportamientos encaminados a conseguir la reproducción material y biológica del grupo (Torrado, 1981).

A la migración le atañen atributos al desarrollo y mitigación de la pobreza, pero no solo corresponden a la migración internacional, sino también a the cyclical labor demand in agriculture to diversify the family income and invest part of the economic resources that they obtain as day laborers in the PPUs.

These people are hired per day or per task, with scarce or null guarantees for labor stability, and their income is conditioned by the excess offer of day workers who move with this purpose, which allows keeping their wages low (Sánchez, 2005). It can be said that, in their majority, the jobs are temporary or seasonal and in face of this, migrants have created routes for labor migration or, sometimes, they return to their places of origin. In the routes, migrants take advantage of cyclical production of agricultural products in different spaces that demand workforce (Velasco, 1995). We are witnessing a temporary migration that is considered a mechanism for exploitation used by capital to appropriate the workforce, whose production and reproduction cost is partially paid (Balán, 1980).

This type of migration has a mobility and seasonal residence in geographic circuits, more or less defined by the agricultural market and work specialization as day laborers in specific crops (Velasco, 2014). In their majority, indigenous people return to their community of origin in the short term, in function of the agricultural cycle of their PPU, taking advantage of the fact that these systems are associated with crops characterized by the intensive use of labor, whose demand is concentrated in specific periods of the agricultural cycle (Sánchez, 2001). It is considered that indigenous mobility is associated with the harvest of agricultural export production in different points, with the ties of identity or belonging and with attention to their family production unit. Migration constitutes a survival strategy of the PPUs, understanding that this belongs to a social class and that, in function of the living conditions that are derived from such an identity, they develop, deliberately or not, specific behaviors directed at attaining the material and biological reproduction of the group (Torrado, 1981).

Migration has to do with attributes for development and poverty mitigation, but these not only correspond to international migration, but rather also to domestic migration, which takes place from spaces in crisis to places with greater economic development, such as the displacement from marginalized agricultural spaces to capitalized 
la interna, que se realiza de los espacios en crisis a lugares con mayor desarrollo económico, como los desplazamientos de los espacios agrícolas marginados a los agrícolas capitalizados; aquí los migrantes rurales desempeñan tareas por un salario inferior y no se puede hablar de un mercado de trabajo en el que se observe una competencia entre los trabajadores por los puestos disponibles, sino de un mercado segmentado (González, 2002); se emplean en actividades en las que las personas locales no están dispuestas a desempeñar, y por salarios inferiores. El impacto de la migración sobre los salarios depende de la calificación de la mano de obra que migra en comparación con la local, lo que conlleva a la exclusión social. Perry (2000) menciona que durante este proceso migratorio, el jornalero y sus familias se ubican en el extremo de la exclusión social, término que hace referencia a la dimensión económica, política e institucional, y sociocultural.

Son abundantes los estudios sobre la migración rural e indígena que se desplaza a las ciudades, a los campos agrícolas de los Estados Unidos o hacia otras zonas agrícolas de exportación de nuestro país, pero se considera que son limitados los que tratan de la migración indígena que se desplaza a espacios con una agricultura de temporal, con altos índice de marginación y con importantes flujos migratorios nacionales e internacionales. El impacto territorial que proviene de la salida de personas genera externalidades negativas; es decir, la decisión individual de salir influencia el potencial de desarrollo territorial colectivo (Mazurek, 2009). En los espacios expulsores de mano de obra se impulsa la transformación de los modos de producción, ante la falta de mano de obra, y ello se debe a que generalmente las personas más jóvenes y capacitadas son las que migran en busca de mejores oportunidades laborales o una mejor remuneración, lo que repercute en la disminución de la población masculina en edad laboral. Nava y Marroni (2003) mencionan que provoca escasez de mano de obra familiar y demanda trabajo asalariado o mecanización que se paga con el dinero enviado por los migrantes. Este es el caso del municipio de estudio.

\section{Metodología}

Se realizó una revisión bibliográfica exhaustiva sobre migración, con énfasis en la realizada por indígenas en espacios agrícolas. Se realizaron recorridos agricultural spaces; in the latter, rural migrants perform tasks for a lower salary and there cannot be talk of a labor market where there is competition between workers for the available positions, but rather of a segmented market (González, 2002); they are employed in activities where local people are not willing to work and for lower salaries. The impact of migration on salaries depends on the qualification of the workforce migrating in comparison to the local, which leads to social exclusion. Perry (2000) mentions that during this migratory process, the day laborer and his/her family are located on the extreme of social exclusion, a term that refers to the economic, political and institutional, and sociocultural dimensions.

The studies regarding rural and indigenous migrants who move to the cities and to the agricultural fields in the United States or towards other agricultural export zones in our country are abundant, but it is considered that those that delve into indigenous migrants who move to spaces with seasonal agriculture, with high marginalization index and with important national and international migratory fluxes, are limited. The territorial impact that comes from the exit of people generates negative externalities; that is, the individual decision of leaving influences the collective potential for territorial development (Mazurek, 2009). In the spaces expulsing workforce, there is a drive to transform production modes, in face of the lack of workforce, and this is because generally the younger and trained people are those who migrate in search for better work opportunities or better pay, and this has an impact on the decrease in the working-age masculine population. Nava and Marroni (2003) mention that this provokes scarcity in family labor and calls for paid work or mechanization that is paid with the money sent by migrants. This is the case of the municipality being studied.

\section{Methodology}

An exhaustive bibliographical review was done on migration, with an emphasis on the migration performed by indigenous people in agricultural spaces. Field visits were carried out in the municipality of study and the unit of analysis was the agricultural day laborers who work in Calpan, Puebla. The interviewees were selected through 
de campo por el municipio de estudio y la unidad de análisis fueron los jornaleros agrícolas que trabajan en Calpan, Puebla. Los entrevistados fueron seleccionados mediante el método de la bola de nieve lineal, ya que se carece de un marco de muestreo. Se aplicaron 76 cuestionarios que contienen variables sociales y económicas. Para la interpretación de resultados se formaron dos grupos, tomando en cuenta la procedencia de los migrantes: región norte y región Tehuacán y Sierra Negra. En el análisis de datos se utilizó estadística paramétrica y no paramétrica.

El municipio de Calpan (Figura 1) se localiza en la parte centro oeste del estado de Puebla, en los paralelos $19^{\circ} 06^{\prime} 36^{\prime \prime}$ y $19^{\circ} 41^{\prime} 12^{\prime \prime} \mathrm{N}$ y los meridianos $98^{\circ} 23^{\prime} 54^{\prime \prime}$ y $98^{\circ} 32^{\prime 2} 24^{\prime \prime} \mathrm{O}$; su extensión geográfica es de $53.59 \mathrm{~km}^{2}$ (INEGI, 2014).

La población del municipio en 2010 ascendía a 13730 habitantes y representaban $0.2 \%$ de la población en el estado. La Población Económicamente Activa (PEA) ocupada ascendía a 4419 personas; de estas, $57 \%$ trabaja en el sector primario. La superficie sembrada en el municipio fue de 2252 hectáreas de maíz y 366 hectáreas de frijol, que representaron menos de $0.6 \%$ de la superficie estatal y un volumen de producción de 4664 y 402 toneladas, the linear snowball method, since there is not a sampling framework. Seventy six questionnaires with social and economic variables were applied. For the interpretation of results, two groups were formed, taking into account the origin of the migrants: northern region and Tehuacán-Sierra Negra region. In the data analysis, parametric and non-parametric statistics were used.

The municipality of Calpan (Figure 1) is located in the central-western part of the state of Puebla, at parallels $19^{\circ} 06^{\prime} 36^{\prime \prime}$ and $19^{\circ} 41^{\prime} 12^{\prime \prime} \mathrm{N}$, and meridians $98^{\circ} 23^{\prime} 54^{\prime \prime}$ and $98^{\circ} 32^{\prime} 24^{\prime \prime} \mathrm{W}$; its geographic extension is $53.59 \mathrm{~km}^{2}$ (INEGI, 2014).

The municipality's population in 2010 was 13730 inhabitants and represented $0.2 \%$ of the population in the state. The occupied Economically Active Population (EAP) was 4419 people; of these, $57 \%$ worked in the primary sector. The surface cultivated in the municipality was 2252 hectares of maize and 366 hectares of beans, representing less than $0.6 \%$ of the state surface and a production volume of 4664 and 402 tons, respectively (INEGI, 2014). These are the most important crops in the municipality and $71 \%$ of the municipal surface was destined to agricultural and livestock activities (INAFED-Instituto Nacional
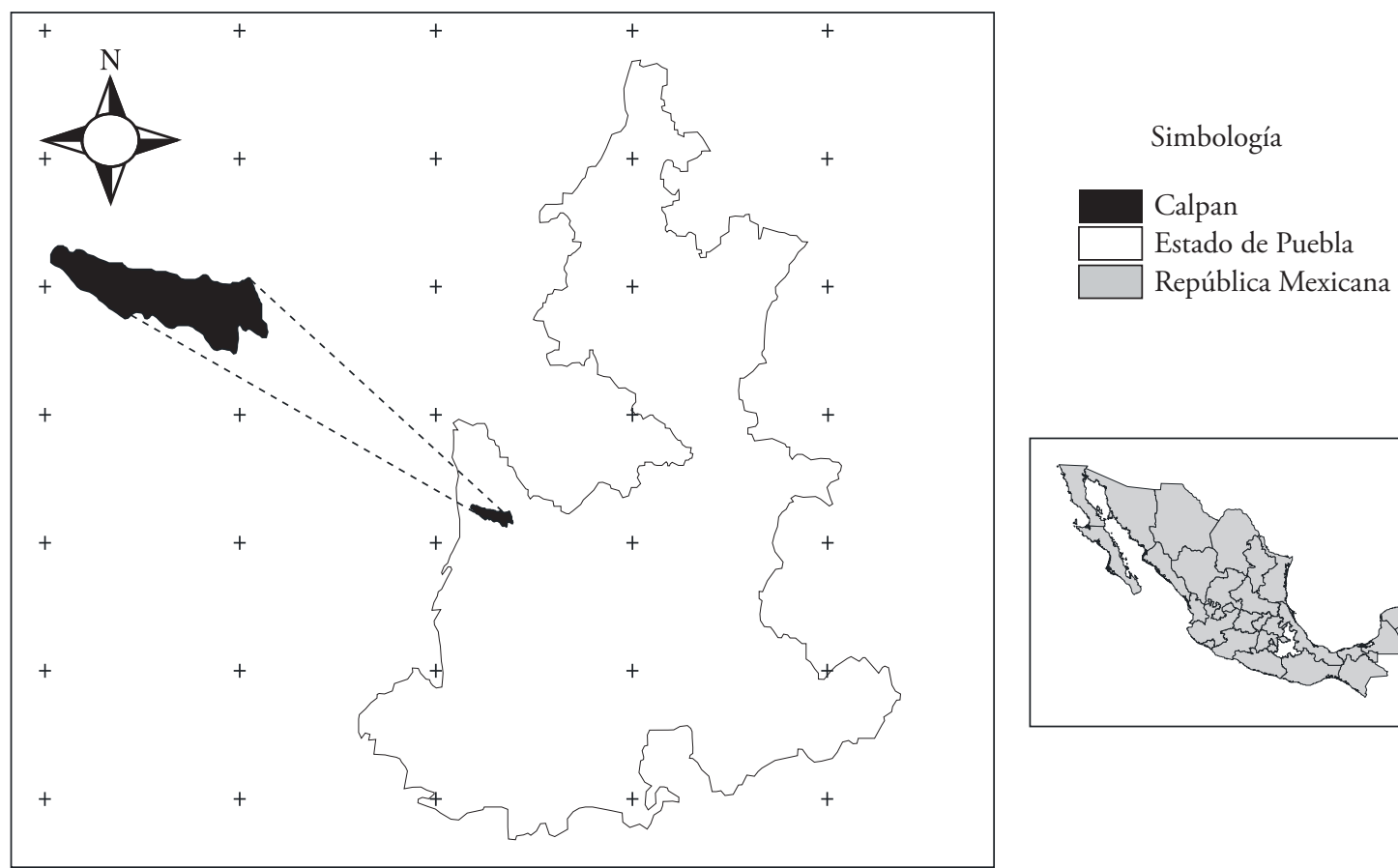

Fuente: elaboración propia. • Source: author’s elaboration.

Figura 1. Ubicación espacial del municipio de Calpan.

Figure 1. Spatial location in the municipality of Calpan. 
respectivamente (INEGI, 2014). Estos son los cultivos más importantes del municipio y se destinó $71 \%$ de la superficie municipal a la actividad agropecuaria (INAFED-Instituto Nacional del Federalismo. 2010). De su población, $80.1 \%$ se encontraba en pobreza; de ésta, $60.1 \%$ presentaba pobreza moderada y $20 \%$ se situaba en pobreza extrema. Además, presenta un grado de intensidad migratoria internacional alto (CONAPO, 2011). Los datos proporcionados ponen de relieve que el municipio de estudio tiene problemas de pobreza y migración.

\section{JORNALEROS INDÍGENAS EN EL MUNICIPIO DE CALPAN}

Los municipios de procedencia de los entrevistados son inminentemente pobres y marginados; no son capaces de generar los empleos necesarios y con un ingreso adecuado para su población, de ahí la migración. El estado de Puebla es uno de los principales expulsores de jornaleros indígenas hacia las zonas agrícolas altamente tecnificadas o capitalizadas del país. Sobre el origen de los migrantes que laboran en el municipio de Calpan se tiene que provienen de la Sierra Norte y de la región de Tehuacán y Sierra Negra. Los primeros son originarios de los municipios de Hermeregildo Galeana (52.2\%) y de Amixtlán, Olintla, Tepango de Rodríguez y San Felipe Tepatlán; y los de la región Tehuacán y Sierra Negra son oriundos de Ajalpan, Coyomeapan, Cohetzala, Eloxochitlán y Tehuacán. En 2010, los municipios de Calpan y Cohetzala poseían un alto índice de intensidad migratoria internacional, en Ajalpan era medio y en los otros municipios era de bajo a muy bajo. La migración de las regiones indígenas a Calpan es un fenómeno geográfico interregional que establece relaciones interétnicas entre los espacios expulsores $\mathrm{y}$ atractores.

En Latinoamérica, México es uno de los países con mayor número de personas indígenas. En 2010, a escala nacional, $6.7 \%$ de su población hablaba algún idioma y en el estado de Puebla, 11.7 \%. Este porcentaje lo coloca como uno de los estados con mayor número de hablantes de una lengua indígena. Estos datos son relativos, ya que el Estado reconoce 61 idiomas indígenas, pero existen más grupos étnicos que no son reconocidos debido al no uso propio de un idioma, por el mayor o menor acercamiento a lo prehispánico y por la identidad establecida en del Federalismo. 2010). Of the population, $80.1 \%$ was found in poverty; of this, $60.1 \%$ presented moderate poverty and $20 \%$ was in extreme poverty. Also, there is a high degree of international migratory intensity (CONAPO, 2011). The data provided highlight that the municipality in study has poverty and migration problems.

\section{INDIGENOUS DAY LABORERS IN THE MUNICIPALITY OF CALPAN}

The municipalities of origin of those interviewed are imminently poor and marginalized; they are not capable of generating the necessary jobs with an adequate income for their population, and migration arises as a result of this. The state of Puebla is one of the main expulsing states for indigenous day laborers who go to highly technified or capitalized agricultural zones in the country. Regarding the origin of the migrants who work in the municipality of Calpan, there are those who come from Sierra Norte and those from the region of Tehuacán and Sierra Negra. The first are originally from the municipalities of Hermeregildo Galeana (52.2 \%) and from Amixtlán, Olintla, Tepango de Rodríguez and San Felipe Tepatlán; the latter, from the Tehuacán-Sierra Negra region are originally from Ajalpan, Coyomeapan, Cohetzala, Eloxochitlán and Tehuacán. In 2010, the municipalities of Calpan and Cohetzala had a high index of international migratory intensity, in Ajalpan it was medium and in the other municipalities it was from low to very low. Migration from indigenous regions to Calpan is an inter-regional geographical phenomenon that establishes inter-ethnic relationships between the expulsing and attracting spaces.

In Latin America, México is one of the countries with highest number of indigenous people. In 2010, at the national scale, $6.7 \%$ of the population spoke some indigenous language, and in the state of Puebla, $11.7 \%$. This percentage places it as one of the states with highest number of speakers of an indigenous language. These data are relative, since the State recognizes 61 indigenous languages, but there are more ethnic groups that are not recognized because there is not proper use of a language, as a result of their greater or lesser approach to the pre-Hispanic scope, and because of the identity established in social relationships of each community structure 
las relaciones sociales de cada estructura comunitaria (Sandoval, 2002). Todos los entrevistados se consideraron indígenas y $56.6 \%$ habla algún idioma; en la Sierra Norte de Puebla, $44.5 \%$ de sus pobladores habla un idioma indígena, como náhuatl, otomí y totonaco (Serrano, 2006). Los resultados encontrados manifiestan que los entrevistados se consideran indígenas, a pesar de que no hablan algún idioma propio de su etnia, y son muy similares a los reportados por Serrano. Con respecto a su distribución espacial, la Comisión Nacional para el Desarrollo de los Pueblos Indígenas (CDI, 2006) menciona que $60 \%$ (6.02 millones de personas) vive en municipios indígenas y 4.2 millones habitan en municipios donde su presencia es minoritaria; ello obedece a particularidades históricas locales, como la migración a las grandes ciudades o a los espacios rurales como jornalero. En este contexto los pueblos indígenas son una categoría especial de minorías.

Con respecto a su situación económica, $86.8 \%$ de los entrevistados se consideró pobre, lo que significa que la pobreza alcanzó a la mayor parte de la población de las regiones; no se encontró diferencia estadística $\left(c^{2}=0.857, p=0.355\right)$ entre los entrevistados que hablan o no un idioma indígena, de procedencia de los migrantes. En los estudios referentes a la migración laboral internacional o nacional se menciona que los migrantes parten jóvenes de su lugar de origen, debido a que suelen enfrentar menores costos de traslado y tienen mayores ganancias a largo plazo, debido a que tienen un mayor grado de escolaridad y mayores oportunidades de trabajo (World Bank, 2007). En las regiones de estudio los resultados muestran que los entrevistados son hombres adultos (40.7 ańos); los migrantes de la Sierra Norte (42.0 años) son mayores que los de la región Tehuacán y Sierra Negra (38.5 años) y los del municipio de Coyomeapan son más jóvenes (32 años). De acuerdo con el INEGI (2004), caen dentro del rango de edad de movilidad espacial de este tipo de población, que se da entre los 15 y 44 años. Los resultados ponen de manifiesto que la edad de los migrantes internacionales es distinta a la de la población indígena jornalera; tienen una edad mayor, se desplazaron al interior del estado para laborar en un municipio con población indígena dispersa y que basa su economía en la agricultura de temporal. Los desplazamientos espaciales fueron a regiones rurales relativamente cercanas a su comunidad de origen, fundamentalmente hacia el interior del estado.
(Sandoval, 2001). All the people interviewed considered themselves indigenous and $56.6 \%$ speak some language; in the Sierra Norte of Puebla, $44.5 \%$ of the inhabitants speak an indigenous language, such as Náhuatl, Otomí and Totonaco (Serrano, 2006). The results found manifest that the interviewees consider themselves indigenous, even if they do not speak a language proper of their ethnic group, and are very similar to those reported by Serrano. With regard to their spatial distribution, the National Commission for the Development of Indigenous Peoples (Comisión Nacional para el Desarrollo de los Pueblos Indígenas, CDI, 2006) mentions that $60 \%$ (6.02 million people) live in indigenous municipalities, and 4.2 million reside in municipalities where their presence is minority; this is due to the local historical particularities, such as migration to large cities or rural spaces as day laborers. Within this context, indigenous peoples are a special category of minorities.

In terms of their economic situation, $86.8 \%$ of those interviewed considered themselves poor, which means that poverty reached most of the population in the regions; no statistical difference was found $\left(c^{2}=0.857, p=0.355\right)$ between the people interviewed who speak an indigenous language or not, and the migrants' origin. In the studies that refer to international or domestic labor migration, it is mentioned that migrants leave their places of origin while young, because they tend to face less travel costs and have higher earnings in the long term, since they have a higher degree of schooling and better work opportunities (Banco Mundial, 2007). In the study regions, the results show that those interviewed are adult men (40.7 years); migrants from Sierra Norte (42.0 years) are older than those from the TehuacánSierra Negra region (38.5 years), and the ones from the municipality of Coyomeapan are the youngest (32 years). According to INEGI (2004), they fall within the age range of spatial mobility of this type of population, which takes place between 15 and 44 years of age. The results highlight that the age of international migrants is different than that of the day laborer indigenous population; they are older and they move inside the state to work in a municipality with disperse indigenous population that bases its economy on seasonal agriculture. The spatial displacements were to rural regions that are relatively close to their community of origin, mainly inside the state. 
En su mayoría, los entrevistados están casados $(85.5 \%)$ y tuvieron una escolaridad de 2.3 años; destaca el hecho de que $53.9 \%$ no asistió a la escuela. Se encontró una correlación negativa $(r=-0.636$; $\mathrm{p}=0.001)$ que indica que a mayor edad tienen menor escolaridad y ésta es muy inferior a la nacional (8.6 años) y similar a la de la población indígena del país; $46.5 \%$ de la población indígena no tiene instrucción o no terminó la primaria (Programa de las Naciones Unidas para el Desarrollo - PNUD, 2010). Los resultados encontrados son propios de los espacios indígenas; es decir, se caracterizan por tener una alta marginación y pobreza, así como bajos niveles educativos, y la brecha de escolaridad en el país aumenta entre los indígenas y no indígenas a partir de la secundaria.

De los migrantes, $31.6 \%$ mencionaron que tienen terrenos para cultivar y poseen 0.406 hectáreas en promedio. Entre la región norte $(0.42 \mathrm{ha})$ y la región Tehuacán-Sierra Negra (0.37 ha) no se encontró diferencia estadística $(\mathrm{t}=0.462, \mathrm{p}=0.650)$ en la cantidad de hectáreas en estos espacios. Romero (2006) encontró que en los espacios cafetaleros a escala regional y del estado tienen 1.45 ha. En el caso de los entrevistados, la superficie con la que cuentan es inferior. El tipo de propiedad de las tierras de los entrevistados es ejidal (91.7\%) y $79.2 \%$ sembró café como uni-cultivo o lo intercaló con maíz o frijol. Al comparar los cultivos sembrados se encontró diferencia estadística significativa $\left(c^{2}=4.364, \mathrm{p}=0.037\right)$ entre regiones, en la Sierra Norte los productores sembraron principalmente café $(87.7 \%)$; en la región de Tehuacán y Sierra Negra 37.5 \% cultivó maíz y frijol, y el porcentaje restante, café.

En consecuencia, la migración interregional es más propensa a ocurrir entre las personas que tienen una menor superficie de tierra que los que cuentan con una mayor cantidad de terreno que sembrar. En un estudio realizado en una región cafetalera del estado de Puebla, Ramírez y Juárez (2008) mencionan que una de las características de estas personas es que son productores minifundistas ( $1.46 \mathrm{ha})$ y que la migración se da fundamentalmente entre sus hijos como consecuencia de la crisis del café y es de carácter regional. También es una consecuencia de la reforma agraria que no repartió ni distribuyó de manera equitativa y suficiente las tierras agrícolas en las regiones de estudio. En espacios del centro oriente del estado de Puebla a los ejidatarios se les repartió un número mayor de tierras. Juárez et al.
In their majority, those interviewed are married $(85.5 \%)$ and had schooling of 2.3 years; the fact that $53.9 \%$ did not attend school is noteworthy. A negative correlation was found $(\mathrm{r}=-0.636 ; \mathrm{p}=0.001)$, indicating that the older they are the less schooling they have, and it is quite below the national figure (8.6 years) and similar to that of the indigenous population in the country; $46.5 \%$ of the indigenous population does not have training or did not finish primary school (United Nations Development Programme, PNUD, 2010). The results found are characteristic of indigenous spaces; that is, they are characterized by having high marginalization and poverty, as well as low educational levels, and the gap in schooling in the country increases between indigenous and non-indigenous starting in secondary school.

Of the migrants, $31.6 \%$ mentioned that they have lands to cultivate and own 0.406 hectares in average. Between the northern region (0.42 ha) and the Tehuacán-Sierra Negra region (0.37), no statistical difference was found $(t=0.462, \mathrm{p}=0.650)$ in the number of hectares in these spaces. Romero (2006) found that coffee-producing spaces at the regional and state scale have $1.45 \mathrm{ha}$; in the case of those interviewed, the surface which they have available is smaller. The type of property of the lands of interviewees is ejido (91.7\%) and $79.2 \%$ cultivated coffee as a single crop or interspersed it with maize and beans. When comparing the crops sown, a significant statistical difference $\left(c^{2}=4.364\right.$, $\mathrm{p}=0.037$ ) was found between regions; in the Sierra Norte region producers sowed primarily coffee $(87.7 \%)$; in the Tehuacán-Sierra Negra region, $37.5 \%$ cultivated maize and beans and the remaining percentage, coffee.

As consequence, inter-regional migration is more prone to happen among people who have a smaller surfaces of land than those who have a larger amount of terrain to cultivate. In a study performed in a coffee-producing region in the state of Puebla, Ramírez and Juárez (2008) mentioned that one of the characteristics of these people was that they are smallscale farmers (1.46 ha) and that migration happens fundamentally among their sons as consequence of the coffee crisis and is of regional character. It is also a consequence of the agrarian reform that did not divide up or distribute equitably and sufficiently the agricultural lands in the study regions. In central- 
(2006) mencionan que en 1995 los ejidatarios explotaban 6.94 hectáreas en promedio que dedicaban a la producción de maíz de temporal. Otro indicador que influyó en la migración es el tipo de cultivos que siembran los entrevistados, cuya rentabilidad económica no es la más apropiada actualmente.

En México, la agudización de las políticas de corte neoliberal buscan insertar al país en la división internacional del trabajo y fortalecer un sistema agrario altamente capitalizado. Por el tipo de cultivos que siembra, este sector requiere mano de obra flexible para disminuir los costos de producción. Una de las estrategias para impulsar el mercado de mano de obra fue disminuir los apoyos gubernamentales a la agricultura de subsistencia, y abrir los mercados agrícolas para influir en el decremento de los precios de las materias primas y en la baja rentabilidad de esta actividad. Estas medidas son una de las causas de la crisis y de la pobreza que actualmente vive el sector agrícola minifundista y que fomenta la venta de tierras, la pluriactividad, el empleo rural no agrícola e intensifica la migración laboral para satisfacer la demanda de trabajo de las zonas agrícolas altamente tecnificadas. Los entrevistados procedentes de la Sierra Norte $(81.3 \%$ ) comentaron que viajaron a Calpan para obtener un mayor ingreso al que ganan en su comunidad y, en los casos de la región de Tehuacán y Sierra Negra, representó 53.6 \%. Otro motivo por el que migraron obedeció a que no existe trabajo en su comunidad de origen; esta respuesta adquirió más importancia entre los oriundos de la región de Tehuacán (42.9\%) que en la Sierra Norte (18.8 \%). Calderón (2006) menciona que la migración se agudizó a partir del Tratado de Libre Comercio (TLC) y que más de 780 mil agricultores, fundamentalmente de granos básicos, han migrado. También repercutió en el abastecimiento de mano de obra de los espacios expulsores, como el caso de Calpan, que tiene un déficit de mano de obra a causa de la migración, que es alta.

Los desplazamientos hacia Calpan no son nuevos, los entrevistados de la Sierra Norte manifestaron desplazarse desde 1993 y los de la región de Tehuacán a partir de 1997. Al comparar los desplazamientos realizados en la década de los noventa y la primera década de este siglo se encontró diferencia estadística $\left(c^{2}=3.979, p=0.046\right)$ que indica que los desplazamientos se agudizaron a Calpan a partir del año 2000; 56.6\% de los entrevistados buscó trabajo en este lugar. Existe correlación negativa entre edad y año que iniciaron a migrar $(\mathrm{r}=-0.636 ; \mathrm{p}<0.001)$, lo eastern spaces of the state of Puebla, ejidatarios were given a higher number of lands. Juárez et al. (2006) mentioned that in 1995 ejidatarios exploited 6.94 hectares in average, which they devoted to rainfed maize production. Another indicator that had an influence on migration is the type of crops that the interviewees sow, whose economic profitability is not the most appropriate nowadays.

In México, sharpening of Neoliberal policies sought to insert the country into the international division of labor and to strengthen a highly capitalized agrarian system. Because of the type of crops sown, this sector requires flexible workforce to decrease production costs. One of the strategies to drive the labor market was to decrease government supports for subsistence agriculture, and to open agricultural markets to influence the decrease of raw material prices and the low profitability of this activity. These measures are one of the causes of the crisis and of the poverty that the smallholding agricultural sector now experiences, which fosters land sale, pluriactivity, non-agricultural rural employment and intensifies labor migration to satisfy the labor demand in highly technified agricultural zones. The interviewees from Sierra Norte $(81.3 \%)$ mentioned that they travelled to Calpan in order to obtain a higher income than what they earn in their community, and in the cases of the Tehuacán-Sierra Negra region, they represented $53.6 \%$. Another cause for their migration was the lack of employment in their communities of origin; this response acquired more importance among residents of the Tehuacán region $(42.9 \%)$ than in Sierra Norte (18.8\%). Calderón (2006) mentioned that migration worsened since the onset of the Free Trade Agreement (NAFTA), and that more than 780 thousand farmers, fundamentally of basic grains, have migrated. This also had repercussions on the supply of workforce in the expulsing spaces, as in the case of Calpan, where there is a workforce deficit because of migration, which is high.

Displacements towards Calpan are not new; the interviewees from Sierra Norte manifested that they have moved since 1993 and those from the Tehuacán region since 1997. When comparing the displacements that occurred in the decade of the 1990 s and the first decade of this century, a statistical difference $\left(c^{2}=3.979, p=0.046\right)$ was found indicating that displacements to Calpan increased since the year $2000 ; 56.6 \%$ of those interviewed sought work in 
que significa que a mayor edad de los entrevistados, mayor experiencia migratoria hacia este lugar. Ramírez y Juárez (2010) comentan que a partir de 2000 se intensificó el proceso migratorio, producto de la crisis cafetalera y fue básicamente interregional.

Rojas (2009) menciona que la incorporación de México al TLC contribuyó a la agudización de la inequidad y la desigualdad, así como al aumento de la pobreza y la migración rural, reflejándose en el incremento de la desnutrición infantil de los espacios rurales y los pueblos indígenas. Por este motivo, 96.1\% de los entrevistados acude año con año a trabajar a este municipio; del total de entrevistados, $64.5 \%$ fue invitado por sus vecinos, $30.3 \%$ se enteró por un amigo que trabaja en Calpan y el porcentaje restante escuchó a sus vecinos cuando hablaban de que existía empleo. La presencia de indígenas en las zonas agrícolas obedece a que las redes establecidas entre migrantes están formadas hace muchas décadas y el trabajo es regularmente seguro (Rojas, 2013). Se observó que las redes de este tipo de migrantes no están desarrolladas en comparación con las de otros espacios rurales, como los del centro-oriente de Puebla que migran a los Estados Unidos. Castillo et al. (2007) mencionan que las redes migratorias juegan un papel fundamental para encontrar trabajo, ya que los parientes y amigos que migraron ayudan a los futuros migrantes a encontrar empleo. Los entrevistados de la Sierra Norte tuvieron más problemas para encontrar trabajo $\left(c^{2}=17.39, p<0.001\right)$, en comparación con los de la región de Tehuacán. Se observó que las personas que tuvieron más dificultades fueron los que escucharon a sus vecinos comentar que había empleo.

Los entrevistados trabajaron en Calpan durante 5.7 meses al año en promedio. Se encontró diferencia entre regiones con respecto a su estancia laboral; los de la sierra norte tuvieron una estancia promedio mayor (6.56 meses) que los de la región de Tehuacán y Sierra Negra (4.39 meses) y se dio de junio a febrero. Los de la región norte $(83.4 \%)$ y los de Tehuacán y Sierra Negra $(71.5 \%)$ trabajaron de octubre a febrero, fundamentalmente. En Calpan, en este periodo se inician las actividades de cosecha de los frutales, maíz y frijol; es por ello que su contratación se dio en esos meses. Este tipo de resultados son similares a los encontrados por Ramírez y Juárez (2009) en relación con el trabajo que realizan los migrantes productores de café cuando salen de su comunidad. La mitad de this place. There is a negative correlation between the age and the year when migration began $(r=-$ 0.636; $\mathrm{p}<0.001$ ), which means that the older the interviewees, the more migratory experience they have towards this place. Ramírez and Juárez (2010) mentioned that since 2000 the migratory process has intensified, product of the coffee-producing crisis, and that it was basically inter-regional.

Rojas (2009) mentioned that the incorporation of México to NAFTA contributed to the worsening of inequity and inequality, as well as to the increase of poverty and rural migration, reflected in the increase of child malnutrition in rural spaces and indigenous towns. For this reason, $96.1 \%$ of those interviewed resort year after year to working in this municipality; of the total interviewees, $64.5 \%$ were invited by their neighbors, $30.3 \%$ found out from a friend who works in Calpan, and the remaining percentage heard their neighbors talking about the availability of work. The presence of indigenous people in the agricultural zones is a result of networks established among migrants, which have been formed for many decades, and of the fact that employment is commonly secure (Rojas, 2013). It was observed that networks of this type of migrants are not developed in comparison to those of other rural spaces, as in the center-east of Puebla where they migrate to the United States. Castillo et al. (2007) mentioned that migratory networks play a fundamental role to find work, since relatives and friends who migrate before help the future migrants to find employment. The interviewees from Sierra Norte had more problems finding work $\left(\mathrm{c}^{2}=17.39, \mathrm{p}<0.001\right)$ than those from the Tehuacán region. It was observed that the people who had more difficulties were those who heard their neighbors commenting that there was work.

The interviewees worked in Calpan for 5.7 months to a year, in average. A difference was found between regions with regard to their work stay; those from Sierra Norte had a higher average stay (6.56 months) than those from the Tehuacán-Sierra Negra region (4.39 months), and this occurred from June to February. Those from the North region $(83.4 \%)$ and those from the Tehuacán-Sierra Negra region (71.5 \%) worked from October to February, mostly. In Calpan, harvesting activities of fruit trees, maize and beans begin during this period; this is why their hiring happened in these months. These types of results are similar to those found by Ramírez and 
ellos se dedica a las actividades de construcción y una cuarta parte trabaja en actividades agrícolas.

La migración laboral que practican los entrevistados es fundamentalmente de retorno, ya que una vez que termina la cosecha o el trabajo regresan a sus lugares de origen. Los entrevistados mencionaron que el trabajo que consiguen es por un periodo corto, ya que son contratados por pequeños agricultores, debido a que no hay mano de obra en el municipio y los que están dispuestos a trabajar cobran caro. Las fechas que los entrevistados trabajan en Calpan, en su comunidad de origen inician las actividades de cosecha de sus productos agrícolas, como el café; en este sentido, la mayoría comentó que descuidan sus actividades agrícolas, a pesar de que su esposa e hijos, fundamentalmente, quedan al pendiente de estas actividades. Maidana (2014) argumenta que las relaciones parentales del migrante actúan como fuerza, lo que los hace no solo regresar periódicamente a sus lugares de origen para mantener vínculos de distinta índole con ellos, sino también para reproducirse.

Con respecto a los ingresos que obtienen se considera que son bajos, con un promedio de $\$ 114.14$ diarios, laborando 11.4 horas diarias durante seis días a la semana. Hernández (2006) menciona que en 2002, en Puebla, $57.07 \%$ de la población de las localidades con alta y muy alta marginación no obtenía ningún ingreso o ganaba menos de un salario mínimo, y que las personas sobreviven porque dedican la mayor parte de su tiempo a obtener bienes en su comunidad, derivado de la producción de bienes de autoconsumo y, en los casos en que obtienen un ingreso, es en montos reducidos. Es importante destacar que el salario que se les pagó lo consideraron regular, pero es más alto a lo que ganaban en su comunidad de origen. En la región de Tehuacán y Sierra Negra los salarios que se ganan son más bajos que en la Sierra Norte, ya que $25 \%$ de los entrevistados mencionaron que en Calpan ganan más que en su lugar de origen. Cea (2004) y Rojas (2013) mencionan que este tipo de población se ocupa en trabajos agrícolas estacionales que requieren una mínima calificación, que sufren una sobreexplotación laboral e ínfima retribución, y son objeto de diferenciación y exclusión social.

Los salarios que ganan los entrevistados de la Sierra Norte constituyen su principal fuente de ingresos y para la otra región representan $75 \%$; en ambas regiones mencionaron que los salarios que
Juárez (2009) with regard to the work that coffeeproducing migrants perform when they leave their community. Half of them are devoted to construction activities, and a fourth works in agricultural activities.

Labor migration practiced by those interviewed is fundamentally of returning migrants, since they return to their places of origin once they finish the harvest or work. The interviewees mentioned that the work they get is for a short period, since they are hired by small-scale farmers, because there is no workforce in the municipality and those who are willing to work are expensive. The dates that the interviewees worked in Calpan, harvest activities for their agricultural products, such as coffee, begin in their communities of origin; in this sense, most mentioned that they neglect their agricultural activities, even if their wives and children, mainly, are left in charge of these activities. Maidana (2014) argues that kinship relationships of the migrant act as strength, making them not only return to their places of origin periodically to maintain links of a different nature with them, but also to reproduce.

With regard to the income they obtain, it is considered that it is low, with an average of $\$ 114.14$ daily, working 11.4 hours a day for six days a week. Hernández (2006) mentioned that in 2002, in Puebla, $57.07 \%$ of the population in the localities with high and very high marginalization did not obtain any income or earned less than the minimum wage, and that people survive because they devote most of their time to obtaining goods in their community, derived from the production of goods for personal consumption, and in the cases when they obtain some income, it is in small amounts. It is important to highlight that they considered the salary paid to them as ordinary, although it is higher than what they earned in their community of origin. In the Tehuacán-Sierra Madre region the salaries earned are lower than in Sierra Norte, since $25 \%$ of those interviewed mentioned that in Calpan they earn more than in their places of origin. Cea (2004) and Rojas (2013) mentioned that this type of population is occupied in seasonal agricultural jobs that require minimum qualification, who suffer labor overpopulation and negligible retribution, and are subject of differentiation and social exclusion.

The salaries that those interviewed in Sierra Norte earn constitute their main source of income and, for the other region, they represent $75 \%$; in 
percibieron en Calpan durante su estancia laboral son superiores a los que ganarían en su región de procedencia. Hoy en día las actividades agropecuarias han perdido importancia como fuente de ingreso; en 1992 los ingresos por estas actividades representaban casi $50 \%$ de los de la población de los estados de la república donde predominan las actividades agropecuarias; en 2006 este ingreso representó menos de 10\% (Esquivel, 2009). Ello obedeció a las diversificación de actividades y, entre ellas, destaca la de vender su fuerza de trabajo.

Se encontró diferencia con respecto a cómo los entrevistados gastan el dinero que ganaron. Los de la Sierra Norte lo destinaron fundamentalmente a la manutención de la familia $(89.3 \%)$ y los de la región de Tehuacán y Sierra Negra también lo utilizaron para la manutención y construcción de su casa (78.6 \%). Velázquez (2013) hace una contextualización histórica de la migración indígena del Istmo de Veracruz y sobre el ingreso que obtienen estas personas, y menciona que no los destinan solamente a la remodelación o construcción de la vivienda, sino que, además, una parte es para la manutención de la familia durante su estancia en su pueblo antes de migrar nuevamente. Es importante mencionar que $59.2 \%$ pagó hospedaje por una cantidad de \$577.7 mensuales. La alimentación fue pagada por la persona que los empleaba $(90.8 \%)$ y, en lo que respecta a dónde consideran ellos que comen mejor, $93.8 \%$ de los oriundos de la Sierra Norte manifestaron que es el lugar donde trabajaban, mientras que de aquellos que son de la región de Tehuacán, $57.1 \%$ dijo que en su trabajo y 28.6 que en su comunidad. En conclusión, se puede decir que $94.7 \%$ de los entrevistados mencionaron que viven mejor en Calpan que en su comunidad de origen.

\section{Conclusiones}

Los resultados encontrados muestran que en los espacios indígenas hay una alta marginación y pobreza, lo cual se refleja en los bajos niveles educativos y en el tamaño de sus unidades de producción familiar. Sus cultivos no tienen la rentabilidad económica suficiente para su reproducción. Esta realidad de la unidades de producción familiar estudiadas impulsa la migración interregional que realizan año con año y se puede decir que la migración laboral es más propensa entre las personas que tienen una mayor edad both regions, they mentioned that the salaries they earned in Calpan during their labor stay are higher than those earned in their region of origin. Today, agricultural and livestock activities have lost importance as a source of income; in 1992 income from these activities represented almost $50 \%$ of those from population in the states in the republic where agricultural and livestock activities predominate; in 2006, this income represented less than $10 \%$ (Esquivel, 2009). This responded to the diversification of activities and, among these, selling their labor stands out.

A difference was found with regard to how the interviewees spend the money they earned. Those in Sierra Norte destined their money fundamentally to supporting the family $(89.3 \%)$ and those from the Tehuacán-Sierra Norte region also used it for supporting their family and building their houses (78.6\%). Velázquez (2013) made an historical contextualization of the indigenous migration of the Veracruz Isthmus and of the income that these people obtain, and he mentioned that they don't allocate it solely to the remodeling or building of their houses, but rather, also, that a part is for supporting their families during their stay in their town before migrating again. It is important to mention that $59.2 \%$ paid for lodging for an amount of $\$ 577.7$ monthly. Food was paid for by the person who hired them $(90.8 \%)$, and in regard to where they consider that they eat better, $93.8 \%$ of the residents of Sierra Norte manifested that it is at the place where they work, while of those from the Tehuacán region, 57.1 $\%$ said at work and $28.6 \%$ in their community. In conclusion, it can be said that $94.7 \%$ of those interviewed mentioned that they live better in Calpan then in their community of origin.

\section{Conclusions}

The results found show that there is high marginalization and poverty in indigenous spaces, which is reflected in the low educational levels and in the size of their family production units. Their crops do not have the sufficient economic profitability for their reproduction. This reality of the family production units studied drives the inter-regional migration that takes place year after year, and it can be said that labor migration is more prone to happen among people who are older and have less land 
y menor superficie de tierra que los que cuentan con una mayor cantidad de terreno que sembrar. Los desplazamientos espaciales fueron a regiones rurales relativamente cercanas a su comunidad de origen, fundamentalmente hacia el interior del estado.

Las redes que han establecido los migrantes no están desarrolladas en comparación con las establecidas en otros espacios rurales. Se practica una migración de retorno y trabajaron en la cosecha de productos agrícolas de temporal casi medio ańo, justo en la época en que se necesita mano de obra en su región de procedencia, descuidando las actividades agrícolas. Fueron contratados por pequeños agricultores de Calpan, debido a que en este espacio la mano de obra es escasa, producto de su propia migración, ya sea nacional o internacional. Los jornaleros migraron para obtener un mayor ingreso y se consideró que perciben ingresos bajos, pero ellos opinaron que son regulares e incluso mayores, en comparación con los que obtenían en su comunidad de origen.

Los ingresos obtenidos son utilizados fundamentalmente para su manutención y, en segundo lugar, para construir su casa. A pesar de que ganan más dinero, el trabajo que realizan es más prolongado, laboran más de ocho horas diarias y a cambio su empleador les proporciona alimentación. Este tipo de ingresos van adquiriendo mayor fuerza entre los migrantes o jornales, al constituirse en la principal fuente de ingresos para un importante porcentaje de entrevistados. Las jornadas de trabajo son superiores a las permitidas para obtener mayores ingresos. Es importante destacar que, a pesar de que están fuera de su comunidad, mencionaron que viven mejor en el municipio de Calpan. Se concluye que para los jornaleros, hoy en día las actividades agropecuarias van perdiendo importancia como fuente de ingreso.

\section{Literatura Citada}

Arango, Joaquín. 2003. La explicación teórica de las migraciones: luz y sombra. Revista Migración y Desarrollo, octubre No 1. México. pp: 1-30.

Arango, Joaquín. 1985. Las leyes de las migraciones de E. G. Ravenstein, cien años después. Revista Española de Investigaciones Sociológicas, No. 32. España. pp: 7-26,

Balán, Jorge. 1980. Migraciones temporarias y mercado de trabajo rural en América Latina. Revista Centro de Estudios de Estado y Sociedad, Vol. 3, No. 3, Argentina. pp: 5-34.

Bermúdez, Roberto. 2008. La migración: una constante nacional y universal. Algunas causas y consecuencias. Revista Trabajo Social, No. 19. México. pp: 23-34.

Banco Mundial. 2014. 2.1 Indicadores del desarrollo mundial: surface than among those who have a larger plot of land to cultivate. The spatial displacements were to rural regions relatively close to their communities of origin, fundamentally towards the state interior.

The networks that migrants have established are not developed in comparison to those established in other rural spaces. A returning migration is practiced, and they work in the harvest of rainfed agricultural products for almost half a year, precisely during the season that labor is needed in their regions of origin, thus neglecting their agricultural activities. They were hired by small-scale farmers in Calpan, because in this space the workforce is scarce, product of their own migration, whether domestic or international. Day laborers migrated to obtain a higher income and it is considered that they earn low wages, but they are of the opinion that they are regular and even higher, in comparison to what they obtain in their community of origin.

The income obtained is used fundamentally for their support, and in second place, to build their house. In spite of earning more money, the work they carry out is longer, they work more than eight hours daily and in exchange their employer provides food. This type of income is becoming more popular among migrants or day laborers, as it is constituted as the main source of income for an important percentage of interviewees. The labor days are longer than those allowed to obtain higher income. It is important to highlight that although they are outside their communities, they mentioned that they lived better in the municipality of Calpan. The conclusion is that for day laborers of today, agricultural and livestock activities are losing importance as a source of income.

- End of the English version -

Dinámica de la población. Página Web: file:///G:/articulos\%20transitorios/Nueva\%20busqueda\%20articulo $\% 20$ y\%20libros/estadisticas/datos $\% 20$ poblacion $\% 20$ mundial\%202013.htm Consultado el 14 de septiembre de 2014.

Boisier, Sergio. 2006. América Latina en un medio siglo (1950/2000): el desarrollo, ¿¿dónde estuvo? Revista Investigaciones Regionales, No. 9. España. pp: 145-167.

Calderón, Georgina. 2006. La inserción del capital en los espacios rurales e indígenas en México. In: Geraiges de Amalia Inés, Arroyo, Mónica Silveira María Laura (coord). América Latina: cidade, campo e turismo. CLACSO, Consejo Latinoamericano de Ciencias Sociales, San Pablo. pp. 243-261.

Castillo, Sasha, José Pedro Juárez, Benito Ramírez, y Gustavo 
E. Rojo. 2007. Política Agrícola y Migración Campesina: El Caso del Municipio de San Juan Atenco, Puebla, México. Revista CIMEXUS, Vol. 2, No. 2, México. pp: 83-102.

Cea, María Elena. 2004. La migración indígena interestatal en la península de Yucatán Revista Investigaciones Geográficas, No. 55, México. pp: 122-142.

CEPAL. 2013. Anuario Estadístico de América Latina y El Caribe. CEPAL, Naciones Unidas. 221 p.

CONAPO. 2011. Descripción de la base de datos del índice de intensidad migratoria México-EU por municipio, 2010. Estimaciones del CONAPO con base en el INEGI, Censo de Población y Vivienda 2010.

CONAPO. 2014. Proyección de hogares indígenas de México y las entidades federativas, 2010-2020. Dirección General de Estudios Sociodemográficos y Prospectiva. http://www. conapo.gob.mx/es/CONAPO/Consultas_Interactivas

Escárzaga, Fabiola. 2004. La emergencia indígena contra el neoliberalismo. Revista Política y Cultura, No. 22, México. pp: 101-121.

Esquivel, Gerardo. 2009. El mercado laboral rural en México: caracterización y agenda de investigación. CEPAL. 101 p.

García, Rodolfo. 2010. Crisis financiera internacional, migración y remesas en América Latina. Revista Ola Financiera, Vol. 3, No. 7, México. pp: 120-147.

Guillén, Héctor. 2007. De la orden cepalina del desarrollo al neoestructuralismo en América Latina. Revista Comercio Exterior, Vol. 57, No. 4, México. pp: 295-313.

González, Amparo. 2002. Efectos macroeconómicos de la inmigración. Impacto sobre el empleo y los salarios de los nativos. Revista Papers, Vol. 66, España. pp: 133-153.

Hernández, José Manuel. 2006. De la miseria a la pobreza (análisis de las migraciones internas indígenas en México). Revista Análisis Económico, Vol. XXI, No. 46, México. pp: 209-235.

Herrera, Fernando, Massieu, Yolanda y Revilla Ulises 2010. Cambios en la migración y en el mercado de trabajo agrícola estadounidense ante la actual recesión mundial. Revista Legislativa de Estudios Sociales y de Opinión Pública, Vol. 3, No. 6, México. pp: 95-128.

INAFED. 2010. Enciclopedia de los municipios y delegaciones de México. INAFED, pág. Web: http://www.inafed.gob.mx/ work/enciclopedia/EMM21 puebla/municipios/21026a.htm

INEGI. 2004. La Población Hablante de Lengua Indígena de Puebla. INEGI, México. 124 p.

INEGI. 2010. México en cifras. Información Nacional, por entidad federativa y municipios. Pág. Web: http://www3.inegi. org.mx/sistemas/mexicocifras/

INEGI. 2011. Principales resultados del Censo de Población y Vivienda 2010. INEGI, México.

INEGI. 2014. Anuario estadístico y geográfico de Puebla 2013. Instituto Nacional de Estadística y Geografía, México.

INMUJERES/CONAPO/CDI/SSA. 2006. Las mujeres indígenas de México: su contexto socioeconómico, demográfico y de la salud. Instituto Nacional de las Mujeres, 135 p.

Juárez, José Pedro, Roser Mayoral, y Benito Ramírez. 2006. Impacto de la reforma agraria neoliberal en una región campesina de México. Resultados en el objetivo de potenciar el mercado de tierras. Revista Cuadernos Geográficos, No. 38, España. pp: 31-44.

Lara, Sara María. 1996. Mercado de trabajo rural y organización laboral en el campo. In: Hubert Carton de Grammont (co- ord). Neoliberalismo y organización social en el campo. ISS/ UNAM Plaza y Valdés, México. pp: 69-112.

Maidana, Carolina Andrea. 2014. Migración indígena, procesos de territorialización y análisis de redes sociales. Revista Interdisciplinar da Mobilidade Humana, No. 41, Brasil. pp: 277-293.

Mazurek, Hubert. 2009. Migraciones y dinámicas territoriales. In: Mazurek, Hubert (ed). Migraciones contemporáneas. Contribución al debate. Postgrado en Ciencias del Desarrollo CIDES-UMSA. pp: 11-33.

Mendoza, José Enrique. 2012. Financiarización y gasto público en México (2000-2011). Latina. Revista Ola Financiera, Vol. 3, No. 7, México. pp: 120-147.

Mendoza, Jesús. 2010. La comunidad indígena en el contexto urbano. Desafíos de sobrevivencia. Centro de Estudios Sociales y de Opinión Pública, Documento de Trabajo núm. $85.41 \mathrm{p}$.

Monroy, Francisco, y José Isabel Juan. 2009. Agricultura y migración campesina. Un estudio para comprender la incorporación del trabajo infantil en una región indígena de México. Argentina de Sociología, Vol. 7, No. 12-13, Argentina. pp: 125-149.

Nava, Martha E., y María da Gloria Marroni. 2003. El impacto de la migración en la actividad agropecuaria de Petlalcingo, Puebla. Revista Agrociencia, Vol. 37, No. 6, México. pp: 657-664.

Perry, Guillermo. 2000. Prólogo a las actas del taller sobre pobreza y exclusión social en América Latina. In: Estanislao, Gacitúa, Sojo, Carlos y Davis, Shelton H. (ed). Exclusión social y reducción de la pobreza en América Latina y El Caribe. Facultad (eds). Latinoamericana de Ciencias Sociales-Sede Costa Rica y Banco Mundial. pp: 9-12.

PNUD (Programa de las Naciones Unidas para el Desarrollo). 2010. Informe sobre Desarrollo Humano de los Pueblos Indígenas en México. El reto de la desigualdad de oportunidades. PNUD. 119 p.

PNUD (Programa de las Naciones Unidas para el Desarrollo). 2013. Informe sobre Desarrollo Humano, 2013. El ascenso del Sur: Progreso humano en un mundo diverso. PNUD. 203 p.

Portales, Luis 2014. Inclusión desde la exclusión: acceso a seguridad social y vivienda por medio del capital social de hogares en pobreza. Revista Sinapsis Social, Vol. 1, No. 1, México. pp: $27-41$.

Ramírez, Benito, y José Pedro Juárez. 2010. Globalización y café: impacto en una región indígena de México. In: Amaya, C. J. y Hernández, M. C, (coord). Globalización y sistemas agroalimentarios. Juan Pablo Editor. pp: 592 - 510.

Ramírez, Benito, y José Pedro Juárez. 2008. Opciones económicas y productivas de reestructuración de las unidades indígenas de producción de café ante la crisis agrícola: estudio en la sierra nororiental de Puebla, México. Revista Perspectivas sociales, Vol. 10, No. 2, México. pp: 115-138.

Ramírez, Benito, y José Pedro Juárez. 2009. Migración en dos municipios indígena del estado de Puebla, México. XXVII Congreso Internacional de la Asociación Latinoamericana de Sociología, 31 de agosto al 4 de septiembre, Buenos Aires, Argentina.

Ravenstein, E. G. 1885. The laws of migration. Journal of the Royal Statistical Society of London, Vol. 48, No. 2, Inglaterra. pp: 167-227.

Rojas, Teresa. 2009. La crisis del sector rural y el coste migratorio en México. Iberofórum, No. 8. México. pp: 40-81. 
Rojas, Teresa 2013. Migración y exclusión social de los trabajadores del campo en México.Educ@upn.mx. Revista universitaria, No. 11, México.

Romero, José Luis 2006. Modelos productivos regionales durante la crisis de bajos precios del café, en el estado de Puebla. Consejo Poblano del Café, Gobierno el estado de Puebla. 44 p.

Ruiz, Naxhelli, y Javier Delgado. 2008. Territorio y nuevas ruralidades: un recorrido teórico sobre las transformaciones de la relación campo-ciudad. Revista Eure, Vol. XXXIV, No. 102, Chile. pp: 77-95.

Sánchez, Kim. 2001. Acerca de enganchadores, cabos, capitanes y otros agentes de intermediación laboral en la agricultura. Revista Estudios Agrarios, No. 17, México. pp: 61-103.

Sánchez, Kim. 2005. Cosechas en Morelos y migración laboral. Revista Inventio, la génesis de la cultura universitaria en Morelos, No. 2. México. pp: 5-12.

Sandoval, Eduardo Andrés. 2002. Grupos etno-lingüísticos en el México del siglo XXI. Revista Papeles de Población, Vol. 8, No. 34, México. pp: 219-235.

Serrano, Carlos. 2014. Anuario de migración y remesas, México, 2014. Fundación BBVA Bancomer, Asociación Civil-Consejo Nacional de Población. 159 p.

Serrano, Enrique. 2006. Regiones indígenas de México. Comisión Nacional para el Desarrollo de los Pueblos Indígenas. $147 \mathrm{p}$.
Tierry, Linck. 2001. El campo en la ciudad: reflexiones en torno a las ruralidades emergentes. Revista Estudios Agrarios, No. 17. México. pp: 9-29.

Torrado, Susana. 1981. Sobre los conceptos de estrategias familiares de vida y proceso de reproducción de la fuerza de trabajo: notas metodológicas. Revista Demografía y Economía, Vol. 15, No. 2. México. pp: 204-233.

Velasco, Laura. 2010. Tijuana indígena. Estudio sobre las condiciones de vida e integración social de la población indígena a la ciudad. Cuadernos de investigación, Comisión Nacional para el Desarrollo de los Pueblos Indígenas, México. 163 p.

Velasco, Laura. 2014. Estudiar la migración indígena. Itinerarios de vida de trabajadores agrícolas en el noroeste mexicano. Revista Economía, Sociedad y Territorio, Vol. XIV, No. 46. México. pp: 715-743.

Velasco, Laura. 1995. Entre el jornal y el terruño: los migrantes mixtecos en la frontera noroeste de México. Revista Nueva Antropología, Vol. 14, No. 47. México. pp: 113-130.

Velázquez, Emilia. 2013. Migración interna indígena desde el Istmo veracruzano: nuevas articulaciones regionales. Revista LiminaR. Estudios Sociales y Humanísticos, Vol. XI, No. 2. México. pp: 128-148.

World Bank 2006. World development report 2007. Development and the Next Generation. World Bank. 317 p. 